\title{
TRANSLATION AND ADAPTATION OF THE "LUMBAR STIFFNESS DISABILITY INDEX" QUESTIONNAIRE INTO PORTUGUESE
}

\author{
TRADUÇÃO E ADAPTAÇÃO DO QUESTIONÁRIO "LUMBAR STIFFNESS DISABILITY INDEX" \\ PARA O PORTUGUES
}

\section{TRADUCCIÓN Y ADAPTACIÓN DEL CUESTIONARIO "LUMBAR STIFFNESS DISABILITY INDEX" PARA EL PORTUGUÉS}

\author{
Angelo Guarçoni Netto, ${ }^{1}$ Luis Marchi, ${ }^{1}$ Gabriel Pokorny, ${ }^{1}$ Rodrigo Amaral, ${ }^{1}$ Rubens Jensen, ${ }^{1}$ Raphael Pratali, ${ }^{1,3}$ Carlos Fernando Herrero, ${ }^{4}$ \\ Charbel Jacob Junior, ${ }^{5}$ Justin Smith, ${ }^{6}$ Emily Miller, ${ }^{6}$ Murilo Daher, ${ }^{7}$ Igor Machado, ${ }^{8}$ Luiz Pimenta ${ }^{1,2}$ \\ 1. Instituto de Patologia da Coluna, São Paulo, SP, Brazil. \\ 2. University of California, San Diego, California, USA. \\ 3. Hospital do Servidor Público Estadual de São Paulo (IAMSPE), São Paulo, SP, Brazil. \\ 4. Faculdade de Medicina de Ribeirão Preto (USP), São Paulo, SP, Brazil. \\ 5. Escola de Medicina da Santa Casa de Misericórdia de Vitória, Espirito Santo, ES, Brazil. \\ 6. University of Virginia Medical Center, Department of Neurosurgery, Charlottesville, VA, USA \\ 7. Universidade Federal de Goiás (UFG), Faculdade de Medicina, Goiânia, GO, Brazil. \\ 8. Irmandade da Santa Casa de Misericórdia de Vitória, Espirito Santo, ES, Brazil.
}

\begin{abstract}
Objective: To develop a version of the Lumbar Stiffness Disability Index (LSDI), translated into Portuguese and culturally adapted for the Brazilian population. Methods: The well-established process of translation into Portuguese and back translation into English was used together with cultural adaptation. Results: Five bilingual translators (English and Portuguese) performed the translation of the Lumbar Stiffness Disability Index (LSDI) from English to Portuguese based on interactive discussions used to arrive at a consensus translation. The translated version of LSDI was then translated into English by a native English-speaking translator who did not know the concepts involved in LSDI. The original LSDI and back translation were compared by a committee formed by the translators responsible for translating the original into Portuguese and a North-American spine surgeon, and because they were considered equivalent, the final version of the LSDI translated into Portuguese and culturally adapted was defined. Conclusions: In order to facilitate global and cross-cultural comparisons of the influence of lumbar stiffness related to spinal arthrodesis in daily activities, this study presents a version of LSDI that has been translated into Portuguese and culturally adapted for the Brazilian population. Level of Evidence; Not Applicable. Prospective Study.
\end{abstract}

Keywords: Spinal Fusion; Range of Motion, Articular; Disability Evaluation; Translating.

\section{RESUMO}

Objetivos: Desenvolver uma versão do Lumbar Stiffness Disability (LSDI) Index, traduzido para o português e culturalmente adaptado para a população brasileira. Métodos: O processo bem estabelecido de tradução para o português e contra-tradução para o inglês foi empregado juntamente com a adaptação cultural. Resultados: Cinco tradutores bilíngües (inglês e português) realizaram a tradução do Lumbar Stiffness Disability Index (LSDI) do inglês para o português baseada em discussões interativas usadas para chegar a uma tradução consensual. A versão traduzida do LSDI foi então traduzida para o inglês por um tradutor nativo de língua inglesa que não sabia os conceitos envolvidos com o LSDI. O LSDI original e a retrotradução foram comparadas por comitê contendo os tradutores responsáveis pela tradução do original para o português e com um cirurgião de coluna vertebral norte americano, e por serem consideradas equivalentes, a versão final do LSDI traduzida para o Português e adaptada culturalmente foi definida. Conclusão: Para facilitar comparações globais e transculturais da influência da rigidez lombar relacionada a artrodese de coluna vertebral nas atividades diárias, este estudo estudo apresenta uma versão do LSDI que foi traduzida para o português e adaptada culturalmente para a população brasileira. Nível de Evodencia; Não Aplicável. Trabalho Prospectivo.

Descritores: Fusão Vertebral; Amplitude de Movimento Articular; Avaliação da Deficiência; Tradução.

\section{RESUMEN}

Objetivo: Desarrollar una versión del Lumbar Stiffness Disability Index (LSDI) traducido al portugués y culturalmente adaptada a la población brasileña. Métodos: El proceso bien establecido de la traducción al portugués y viceversa traducida al inglés se utilizó junto con la adaptación cultural. Resultados: Cinco traductores bilingües (inglés y portugués) Ilevaron a cabo la traducción del Lumbar Stiffness Disability Index (LSDI) del inglés al portugués basada en debates interactivos utilizados para llegar a una traducción consensual. La versión traducida del LSDI fue entonces traducida al inglés por un traductor nativo de lengua inglesa que no conocía los conceptos involucrados con el LSDI. El texto original y la copia de la traducción se compararon por un comité formado por los traductores responsables de la traducción del original al portugués y un cirujano de la columna vertebral norteamericano, y cómo se consideran equivalentes, la versión final traducida al portugués y culturalmente adaptada del LSDI se ha definido. Conclusiones: Para facilitar comparaciones globales y transculturales de la influencia de la rigidez lumbar relacionada con la artrodesis de columna vertebral en las actividades diarias, este estudio presenta una versión del LSDI que ha sido traducida al portugués y culturalmente adaptada a la población brasileña. Nivel de Evidencia; No se aplica. Estudio Prospectivo.

Descriptores: Fusión Vertebral; Rango del Movimiento Articular; Evaluación de la Discapacidad; Traducción.

This study was coducted at the Instituto de Patologia de Coluna (IPC) - São Paulo, SP, Brazi

Corresponding: Angelo Guarçoni Netto, Rua Vergueiro 1421, sala 305, São Paulo, SP, Brasil. 04101-000. angelo_netto@yahoo.com.br 


\section{INTRODUCTION}

Spinal arthrodesis surgery is an increasingly more performed procedure for the treatment of trauma, degenerative diseases, tumors, infection, and spinal deformity. ${ }^{1-2}$ Although spinal arthrodesis procedures many times alleviate the pain and functional disability associated with vertebral disease, the end goal of arthrodesis is to prevent the movement of the affected spinal segments. ${ }^{3}$ However, because the mobility provided by the spine is an integral part of day-daily activities, the stiffness associated with arthrodesis can negatively affect specific abilities, even when the outcome is successful in terms of pain reduction and improved overall functional capacity. ${ }^{3}$

Recently, the Lumbar Stiffness Disability Index (LSDI) questionnaire, designed to evaluate limitations on daily life activities due to segmental stiffness secondary to spinal arthrodesis, was presented. ${ }^{4-5}$ This questionnaire may help to answer patients' questions about the impact of lumbar arthrodesis and reduced spinal mobility in the functional capacity of the individual. Originally published in English, to date there is no version of the LSDI translated into Portuguese and culturally adapted for the Brazilian population. The objective of this study was to develop and present a Portuguese version of the LUMBAR STIFFNESS DISABILITY INDEX (LSDI), ${ }^{6}$ culturally adapted for the Brazilian population.

\section{METHODS}

\section{Translation and Cultural Adaptation Process}

This study presents a translation and cultural adaptation of the LSDI (Table 1), produced through the collaborative efforts of five centers specializing in the treatment of spinal disorders, which together comprise the BRAZILIAN SPINE STUDY GROUP (BSSG).

This is a well-established process that has been used for the translation and cultural adaptation to Brazilian Portuguese of several questionnaires of practical applicability to spinal diseases and which we followed in this project. ${ }^{7-8}$

\section{Initial translation to Brazilian Portuguese}

The initial translation of the LSDI was performed by five bilingual translators whose native language is Portuguese, all of whom are spine surgeons. The five translators worked independently and the versions obtained were compared and discussed until consensus was reached around possible discrepancies among the versions.

\section{Back translation to English}

The version obtained from the consensus of the translation of the LSDI to Portuguese was then back translated to English by a translator who had not participated in the earlier process and was

Tabela 1. Lumbar Stiffness Disability Index.

\begin{tabular}{c|c}
\hline \multicolumn{2}{c}{ Choose the statement that best describes the effect of low back } \\
stiffness on your ability to
\end{tabular}

not knowledgeable about previous process, was a native speaker of English, and was not aware of the concept involved in the scale or of its objective. The goal of the back translation to English was to identify conceptual errors with semantic peculiarities between the languages.

\section{Review by a committee of specialists}

The back-translated English version was compared to the original version, also in English, by a committee made up of the translators responsible for the original translation into Portuguese and a North American spine surgeon, all of whom were aware of the concepts and goals involved in the application of the LSDI. Each member of the committee evaluated the two versions in terms of equivalence and discrepancy in four areas: ${ }^{8-9}$ semantic, idiomatic, experiential, and conceptual. The discrepancies identified were discussed by the group until consensus was reached, thus defining the final version of the LSDI questionnaire in Portuguese, culturally adapted for the Brazilian population.

The study was approved by the Institutional Review Board (No. 82012017.6.0000.5463) and the ICF was not required as there were no research participants in this study.

\section{RESULTS}

As planned, the translation process was the result of consensus among the five translations carried out by spine surgeons and then forwarded for back translation by a bilingual translator who is a native English speaker.

In the next phase, the review by the committee of specialists did not validate the first and second sentences of the back-translated English version of the questionnaire, the first having been translated as lifting-up of your feet in order to put on your underwear and pants while attempting to dress yourself, as the sentence translated as such did not express the concept of limitation.

Thus, we requested the back translator to review the translation and the following version was approved by the committee: bending to your feet in order to put on your underwear and pants while attempting to dress yourself.

In a discussion with the American specialist about the second problematic sentence, which had been back-translated as bending your spinal column region in order to put on your socks and shoes, given that the concept that needed to be conveyed in the original LSDI scale was of bending forward at the waist (bend through your waist - see the scale). So we decided to change the first translation (curve the trunk to put on your socks and shoes) to bend over to put on your socks and shoes. Thus, the sentence was sent back to the back-translator who revised it as bending yourself forward to put on your socks and shoes, a version that was accepted by the American specialist and by the committee. After these discrepancies were cleared up and corrected, we arrived at the final Brazilian Portuguese version. (Table 2)

\section{DISCUSSION}

Tools developed specifically to assess the impact of spinal conditions on the quality of life, such as the Oswestry Disability Index (ODI) and Scoliosis Research Society-22 (SRS-22), allow us to determine the outcome of surgical treatment in reducing pain and deformity and improving the function of the patients. ${ }^{10-11}$ While these tools provide information about functional limitations associated with back and leg pain, they do not seek information about deficits in performing daily life activities due to lumbar stiffness. Less specific quality of life questionnaires, such as Short Form-36 (SF-36), are not often used in clinical studies of patients with lumbar spine diseases, ${ }^{12-13}$ nor do they evaluate the functional limitations caused by stiffness.

Recently, the Lumbar Stiffness Disability Index (LSDI) questionnaire, designed to evaluate limitations on daily life activities due to segmental stiffness secondary to spinal arthrodesis, was presented. ${ }^{4-5}$ This questionnaire may help to answer patients' questions about the impact of lumbar arthrodesis and reduced spinal mobility on the functional capacity of the individual. Moreover, several 
Tabela 2. Índice de Incapacidade por Rigidez Lombar.

Escolha a frase que melhor descreve o efeito da rigidez da região lombar na sua capacidade para

\begin{tabular}{c|c}
\hline $\mathbf{N}^{\mathbf{0}}$ & Questão \\
\hline 1. & $\begin{array}{c}\text { Inclinar-se até seus pés para vestir suas roupas íntimas e } \\
\text { calças enquanto se veste sozinho }\end{array}$ \\
\hline 2. & Curvar-se para calçar meias e sapatos \\
\hline 3. & Dirigir um veículo motorizado (carro, moto, caminhão...) \\
\hline 4. & Realizar higiene pessoal após usar o banheiro \\
\hline 5. & Inclinar-se para frente para pegar um pequeno objeto no chão \\
\hline 6. & Deitar e levantar da cama \\
\hline 7. & Lavar a metade inferior do seu corpo \\
\hline 8. & Entrar e sair de um CARRO \\
\hline 9. & Ter relação sexual \\
\hline 10. & Respostas \\
\hline \multicolumn{2}{|c}{ Opções de resposta e pontuacão para cada item } \\
\hline Pontuação & Não afeta de forma alguma \\
\hline 1 & Mf́nimo efeito \\
\hline 2 & Ne maneira significativa \\
\hline 3 & Não consegue realizar de forma alguma \\
\hline 4 &
\end{tabular}

questions contained in the LSDI are part of the frailty questionnaire (Frailty Index) that can be used to measure the frailty of patients who are candidates for spine surgery. ${ }^{14}$

Originally published in English, to date there is no version of the LSDI translated into Portuguese and culturally adapted for the Brazilian population. Universal use of the same questionnaire is recommended in comparisons of distinct populations as it permits an analysis of both the impact of diseases in different locations and the outcome following different therapeutic approaches. However, there is a limitation in applying it to individuals who have not mastered the language in which the original scale was written, besides the cultural issue..$^{15}$ Thus, questionnaires, scales, and indices should not be just translated, but also culturally adapted for the target population. ${ }^{12}$

\section{CONCLUSION}

To facilitate global and transcultural comparisons of the influence of lumbar stiffness associated with spinal arthrodesis on daily activities, this study presents a version of the LSDI translated into Portuguese and culturally adapted for the Brazilian population.

All authors declare no potential conflict of interest related to this article.

CONTRIBUTION OF THE AUTHORS: Each author made significant individual contributions to this manuscript. LM (0000-0002-3447-0399)*, AGN $(0000-0003-1559-1520)^{\star}$, RA (0000-0003-3007-0571) ${ }^{\star}, \mathrm{MD}(0000-0001-9589-5596)^{\star}, \mathrm{RP}(0000-0002-1758-5485)^{\star}, \mathrm{CFH}(0000-0001-9599-8544)^{\star} ; \mathrm{IMC}^{*}$ $(0000-0003-4291-8736)^{\star}$, CJJ $(0000-0002-1301-5805)^{\star}$, JS (0000-0002-5297-7329)*, LP (0000-0002-5702-5431) and EM (0000-0001-6956-2253)* participated in the elaboration of the idea and the translation of the LSDI questionnaire. LM, AGN, RA, MD, RP, CFH, IMC, CJJ, JS, and EM participated actively in the discussion of the results. LM, GP (0000-0002-7907-8032)*, AGN, and RP participated in the writing and review of the article. ${ }^{\star}$ ORCID (Open Researcher and Contributor ID).

\section{REFERENCES}

1. Deyo RA, Gray DT, Kreuter W, Mirza S, Martin BI. United States trends in lumbar fusion surgery for degenerative conditions. Spine (Phila Pa 1976). 2005;30(12):1441-5.

2. Deyo RA. Back surgery-who needs it? N Engl J Med. 2007:356:2239-43.

3. D'Andrea LP, Guille JT, Letko L, et al. Trunk flexibility and activity/function are significantly less with lumbar fusion in patients with Lenke 1\&2 curve types. Poster session presented at: Scoliosis Research Society 43rd Annual Meeting; 2008; Salt Lake City, UT.

4. Hart RA, Pro SL, Gundle KR, Marshall LM. Lumbar stiffness as a collateral outcome of spinal arthrodesis: a preliminary clinical study. Spine J. 2013;13(2):150-6.

5. Hart RA, Marshall LM, Hiratzka SL, Volpi J, Lynn M, Shannon L, et al. Functional limitations due to stiffness as a collateral impact of instrumented arthrodesis of the lumbar spine. Spine (Phila Pa 1976). 2014; 39(24):E1468- 74.

6. Hart RA, Gundle KR, Pro SL, Marshall LM. Lumbar Stiffness Disability Index: pilot testing of consistency, reliability, and validity. Spine J. 2013:13(2):157-61.

7. Vigatto R, Alexandre NM, Correa Filho HR. Development of a Brazilian Portuguese version of the Oswestry Disability Index: cross-cultural adaptation, reliability, and validity. Spine (Phila Pa 1976). 2007;32(4):481-6.

8. Cook C, Richardson JK, Braga L, Menezes A, Soler X, Kume P, et al. Cross-cultural adaptation and validation of the Brazilian Portuguese version of the Neck Disability Index and Neck Pain and Disability Scale. Spine (Phila Pa 1976). 2006;31(14):1621-7.
9. Guillemin F, Bombardier C, Beaton D. Cross-cultural adaptation of health- related quality of life measures: literature review and proposed guidelines. J Clin Epidemiol. 1993; 46(12):1417-32.

10. Fairbank JC, Pynsent PB. The Oswestry Disability Index. Spine (Phila Pa 1976). 2000;25(22):2940-52.

11. Daltroy JH, Cats-Baril WL, Katz JN, Fossel AH, Liang MH. The North American Spine Society lumbar spine outcome assessment instrument: reliability and validity tests. Spine (Phila Pa 1976). 1996;21(6):741-9.

12. Hagg O, Fritzell P, Romberg K, Nordwall A. The General Function Score: a useful tool for measurement of physical disability. Validity and reliability. Eur Spine J. 2001;10(3):203-10.

13. Grotle M, Brox JI, Vollestad NK. Functional status and disability questionnaires: what do they assess? A systematic review of back-specific outcome questionnaires. Spine (Phila Pa 1976). 2005; 30(1):130-40.

14. Miller EK, Vila-Casademunt A, Neuman BJ, Sciubba DM, Kebaish KM5, Smith JS, et al External validation of the adult spinal deformity (ASD) frailty index (ASD-FI). Eur Spine J. 2018:27(9):2331-8

15. Deyo RA, Battie M, Beurskens AJ, Bombardier C, Croft P, Koes B, et al. Outcome measures for low back pain research: a proposal for standardized use. Spine (Phila Pa 1976). 1998;23(18):2003-13 